\title{
PERSEPSI MASYARAKAT SEKITAR KAWASAN PENGEMBANGAN EKOWISATA AIR PAOH DI DESA PANGKALAN BUTON KECAMATAN SUKADANA KABUPATEN KAYONG UTARA
}

\author{
(community perception around the Paoh water ecotourism development area in Pangkalan \\ Buton Village, Sukadana District, North Kayong Regency)
}

\author{
Fazriansyah, M. Idham, Iskandar \\ Fakultas Kehutanan Universitas Tanjungpura Jl. Daya Nasional, Pontianak 78124 \\ Email : fazriansyah1878@gmail.com
}

\begin{abstract}
North Kayong Regency is a district that has tourism potential, one of that is Paoh water ecotourism which is now developed into Bukit Paoh Villa and Resto. The existence of the development of this new ecotourism has led to different perceptions between individuals in Pangkalan Buton Village, so it is necessary to conduct research of the community around the Paoh water ecotourism development area in Pangkalan Buton Village, Sukadana District, North Kayong Regency. The purpose of this study is to examine people's perceptions of water ecotourism and examine the relationships between perceptions of income, knowledge, and cosmopolitan. This research uses a survey method with purposive sampling technique. The results show the perception of the community around the ecotourism development area in Pangkalan Buton Village, Sukadana Subdistrict, North Kayong Regency which is $52.1 \%$ neutral. There is a significant relationship between people's perceptions of the level of income, level of knowledge, and cosmopolitan towards the development of water ecotourism Paoh in Buton Village, Sukadana District, Kayong Utara Regency
\end{abstract}

Keywords : Development, Ecotourism, suistainable, Community of perception

\section{PENDAHULUAN}

Kabupaten Kayong Utara merupakan suatu daerah yag memiliki potensi wisata yang melimpah salah satunya yakni wisata yang bersifat lingkungan seperti Ekowisata Air Paoh yang berada di Desa Pangkalan Buton Kecamatan Sukadana Kabupaten Kayong Utara. Ekowisata menurut (Kehutanan, 1987) merupakan salah satu bentuk dan merupakan kegiatan yang secara langsung memanfaatkan potensi sumber daya alam dan tata lingkungannya. Sedangkan objek wisata alam ialah sumber daya alam yang berpotensi dan memiliki daya tarik wisatawan serta upaya dala mengelola alam, baik dalam keadaan alami maupun setelah ada usaha budidaya. Prinsip dalam membangun ekowisata yang dikemukakan oleh (Fandeli, 2000) yakni mencegah dan menanggulangi dampak dari aktivitas wisatawan terhadap alam dan budaya, pendidikan konservasi lingkungan, pendapatan langsung untuk kawasan, partisipasi masyarakat dalam perencanaan, dan penghasilan masyarakat.

Ekowisata Air paoh yang berada di Desa Pangkalan Buton ini merupakan ekowisata yang telah ada sejak zaman dahulu dan selalu terjaga kelestariannya oleh masyarakat lokal. Jumlah pengunjung yang datang ke ekowisata 
tersebut terus meningkat setiap tahun, oleh karena itu dibuat suatu ekowisata baru yang berdekatan dengan ekowisata air paoh yakni Ekowisata Bukit Paoh Villa dan Resto yang menawarkan keindahan alam di atas bukit dengan fasilitas pemandian yang airnya menggunakan air paoh dan ada villa serta resto.

Bukit Paoh Villa dan Resto ini merupakan ekowisata yang dikelola oleh pihak swasta dengan melibatkan pemerintah setempat dalam pengembangannya. Adanya ekowisata baru ini menimbulkan keuntungan dan kerugian tersendiri bagi masyarakat desa tersebut. Keuntungan bagi masyarakat setempat ialah semakin dikenalnya desa mereka dengan adanya ekowisata baru ini serta kerugian dari masyarakat setempat ialah sedikitnya masyarakat asli desa tersebut yang bekerja di sana karena mereka mengharapkan adanya ekowisata baru ini akan banyak menyerap pekerja khususnya anak asli desa tersebut.

Hadirnya ekowisata Bukit Paoh Villa dan Resto di Desa mereka menimbulkan persepsi dari masyarakat setempat khususnya masyarakat Desa Pangkalan Buton serta hubungannya antara persepsi masyarakat terhadap tingkat pendapatan, persepsi masyarakat terhadap tingkat pengetahuan, serta persepsi masyarakat terhadap kosmpolitan. Menurut (Ni'am, 2014), persepsi adalah penilaian individu maupun kelompok pada hal yang berkaitan dengan kejadian, objek dengan mengaitkan hal-hal tersebut pada hal yang berkaitan dengan pengalamanpengalaman tersebut.

Tujuan dari penelitian ini yakni mengetahui persepsi dari masyarakat terhadap pengembangan ekowisata ini serta ingin mengetahui hubungan persepsi dari masing-masing faktor yakni tingkat pendapatan, tingkat pengetahuan, dan tingkat kosmopolitan.

\section{METODE PENELITIAN}

Penelitian ini dilaksanakan di Desa Pangkalan Buton Kecamatan Sukadana Kabupaten Kayong Utara. Pengambilan data dilaksanakan selama kurang lebih 2 bulan dimulai pada tanggal 5 mei - 10 juli 2019, dimana subjek penelitiannya adalah masyarakat Desa Pangkalan Buton dan obyek penelitiannya adalah pengembangan ekowisata Bukit Paoh Villa dan Resto. Menggunakan rumus slovin (Silaen, 2013) dalam menentukan jumlah sampel responden dengan cara sebagai berikut :

$\mathrm{n}=\frac{\mathrm{N}}{1+\mathrm{Ne}^{2}}$

Dimana:

$\mathrm{n}=$ Jumlah Sampel responden

$\mathrm{N}=$ Jumlah Populasi responden

e $=$ Persentase ketidaktelitian yang masih dapat di tolerir (20\%).

Berdasarkan perhitungan rumus slovin didapat total responden 94 kepala keluarga dengan jumlah populasi 4780 orang yang terbagi dalam 4 Dusun yakni dusun Air Paoh sebanyak 24 sampel (responden), Dusun Sungai Gali sebanyak 23 Sampel (responden), Dusun Tanjung Belimbing sebanyak 23 sampel (responden), dan Dusun Simpang Empat sebanyak 24 sampel (responden). 
Menggunakan metode pengumpulan data yakni data primer dan data sekunder. Data primer diperoleh dari Observasi, kuisioner penelitian, serta wawancara, sedangkan data sekunder diperoleh dari dokumendokumen yang terkait dengan dengan penelitian tersebut seperti, monografi, peta,serta literatur-literatur yang menunjang data penelitian.

Variabel terikat dari penelitian ini adalah Persepsi Masyarakat Desa Pangkalan Buton, sedangkan variabel bebas dai penelitian ini adalah tingkat pendapatan masyarakat, tingkat Tabel 1. Penilaian Skor Persepsi Masyarakat

\begin{tabular}{llc}
\hline No & Persepsi & Bobot Skor \\
\hline 1 & Sangat Positif & 5 \\
2 & Positif & 4 \\
3 & Netral & 3 \\
4 & Negatif & 2 \\
5 & Sangat negative & 1
\end{tabular}

Sumber: Sugiono, (2011)

Berdasarkan total skor dari nilai bobot masing-masing item pertanyaan selanjutnya dari lima kategori tersebut dirubah menjadi tiga kategori (positif, netral dan negatif). Dengan menggunakamn rumus standar deviasi (Sugiyono, 2011) sebagai berikut :

$\mathrm{SD}=\sqrt{\frac{n \sum x i^{2}-\left(\sum x i^{2}\right.}{n(n-1)}}$

Keterangan :

$\mathrm{SD}=$ Standar Deviasi

$\mathrm{n} \quad=$ Jumlah Responden pengetahuan masyarakat, dan tingkat kosmopolitan.

Analisis data dilakukan menggunakan analisis deskriptif dan analisis inferensial. Analisis deskriptif dalam penelitian ini bertujuan untuk mendeskripsikan variabel terikat penelitian yaitu Persepsi Masyarakat Sekitar Kawasan Pengembangan Ekowisata Air Paoh. Data kualitatif dirubah menjadi data kuantitatif menggunakan system penyesuaian Skala Likert dengan dikelompokkan menjadi lima kategori seperti pada Tabel 1 berikut ini : 
Tabel 2. Persepsi Masyarakat sekitar kawasan pengembangan ekowisata bukit paoh villa dan resto

\begin{tabular}{clccc}
\hline No & Kategori Persepsi & Frekuensi & Persentase & Keterangan \\
\hline 1 & Positif & F1 & X1 & \\
2 & Netral & F2 & X2 & \\
3 & Negatif & F3 & X3 & \\
\hline Total & & $\sum F$ & $\sum x$ & \\
\hline
\end{tabular}

Sumber : Sugiono, (2011)

Analisis deskriptif persepsi dilakukan dengan analisis statistik non parametrik chi kuadrat $\left(\mathrm{x}^{2}\right)$ data di lakukan dengan menggunakan rumus chi kuadrat (Sugiyono, 2011) sebagai berikut:

$X^{2}=\sum_{i=1}^{K} \frac{\left(f_{0}-f_{h}\right)^{2}}{f_{n}}$

Dimana :

$X^{2}=$ chi-kuadrat

$f_{0}=$ frekuensi yang diobservasi

$f_{h}=$ frekuensi yang diharapkan

Analisis inferensial menggunakan

Uji statistik Non Parametrik Korelasi

Pearson. Dengan rumus Korelasi

Pearson (Sugiyono, 2011) sebagai

berikut :

$r=\frac{n \sum x y-\left(\sum x\right)-\left(\sum y\right)}{\sqrt{\left\{n \sum x^{2}-\left(\sum x\right)^{2}\right\}\left\{n \sum y^{2}-\left(\sum y\right)^{2}\right\}}}$

Keterangan :

$\mathrm{r}=$ koefisien korelasi

$\mathrm{n}=$ banyaknya pasangan data $\mathrm{X}$ dan $\mathrm{Y}$

$\sum x=$ total jumlah dari variabel $X_{1}, X_{2}$, dan $X_{3}$

$\sum y=$ total jumlah dari variabel $\mathrm{Y}$

$\sum x^{2}=$ kuadrat dri total jumlah variabel

$X_{1}, X_{2}$, dan $X_{3}$

$\sum y^{2}=$ kuadrat dari total jumlah variabel

$\mathrm{Y}$

$\sum x \mathrm{y}=$ hasil perkalian dari total jumlah variabel $X_{1}, X_{2}, X_{3}$ dan $\mathrm{Y}$
Untuk menganalisis data dengan uji korelasi Pearson, peneliti menggunakan total masing-masing bobot skor data dari hasil pengamatan yang diperoleh dari variabel penelitian dalam bentuk data kualitatif yang dikuantitafkan menggunakan Skala Likert. Untuk menganalisis data hubungan variabel terikat dengan variabel bebas, peneliti menggunakan program SPSS versi 25. Untuk mengetahui ada tidaknya hubungan yang signifikan antara variabel terikat dan variabel bebas maka peneliti menggunakan ketentuan sebagai berikut :

- Nilai hipotesis $\left(H_{0}\right)$ diterima jika nilai signifikan > 0,050 maka dapat disimpulkan tidak terdapat hubungan yang signifikan antara variabel terikat dan variabel bebas.

- Nilai hipotesis $\left(H_{a}\right)$ diterima jika nilai signifikan $<0,050$ maka terdapat hubungan yang signifikan antara variabel terikat dan variabel bebas.

\section{HASIL DAN PEMBAHASAN}

\section{Karakteristik Responden}

Karakteristik responden dalam penelitian ini adalah masyarakat yang berada di dalam Desa Pangkalan Buton yakni Dusun Simpang Empat, Dusun Sungai Gali, Dusun Tanjung Belimbing, 
dan Dusun Air Paoh yang berada di Kecamatan Sukadana Kabupaten Kayong Utara. Responden dipilih dengan cara Purposive Sampling yakni dengan memilih secara tidak acak atau sengaja dipilih secara subjektif (berdasarkan kemauan sendiri) dengan melihat persyaratan nya sebagai berikut :

1. KK dan KTP asal di Desa Pangkalan Buton

2. Lama berdomisili minimal 5 tahun

3. Sehat jasmani dan rohani

4. Orang dewasa (atau yang berumur antara 17-65 tahun)

5. Bisa membaca dan menulis

Kategori umur setiap responden

yang diberikan kuisioner adalah sebagai berikut

1. 17 - 25 tahun : 23 orang

2. 26 - 30 tahun : 16 orang

3. 31 - 40 tahun : 24 orang

Tabel 3. Persepsi Masyarakat Sekitar Kawasan Pengembangan Ekowisata Bukit Paoh Villa dan Resto

\begin{tabular}{ccc}
\hline Keterangan & Frekuensi & Persentase \\
\hline Negatif & 27 & $28,8 \%$ \\
Netral & 49 & $52,1 \%$ \\
Positif & 18 & $19,1 \%$ \\
\hline Total & 94 & $100 \%$
\end{tabular}

Sumber : Data Penelitian, (2019)

Persepsi responden terhadap pengembangan ekowisata Air Paoh di Desa Pangkalan Buton yaitu negatif sebanyak 27 responden $(28,8 \%)$, netral sebanyak 49 responden $(52,1 \%)$, dan negatif sebanyak 18 responden $(19,1 \%)$. Frekuensi persepsi masyarakat terhadap pengembangan ekowisata Air Paoh di Desa Pangkalan Buton.

Persepsi masyarakat yang negatif mereka beranggapan bahwa adanya ekowisata baru berpengaruh pada
4. $41-50$ tahun : 17 orang

5. 51 - 65 tahun : 14 orang

\section{Persepsi Masyarakat Sekitar Kawasan Pengembangan Ekowisata Air Paoh}

Berdasarkan hasil penelitian terkait dengan Persepsi Masyarakat Sekitar Kawasan Pengembangan Ekowisata Air Paoh persepsi masyarakat dalam penelitian ini dikelompokkan menjadi 3 (kategori). berdasarkan wawancara terhadap 94 responden diperoleh persepsi positif 18 responden $(19,1 \%)$, persepsi netral 49 responden $(52,1 \%)$ dan persepsi negatif 27 responden $(28,8$ $\%$ ) dengan jumlah sampel yang berpendapat negatif sebanyak 27 sampel, netral sebanyak 49 sampel, dan positif sebanyak 18 sampel. Lebih jelas dapat dilihat pada Tabel 3. 
ekowisata baru di lingkungan mereka mengingat mereka sudah memiliki ekowisata yang telah mereka pergunakan sejak mereka tinggal di desa tersebut. Faktor-faktor yang mempengaruhi persepsi masyarakat yakni umur, pendidikan formal maupun nonformal, pendapatan dan ketersedian informasi (Novayanti, 2017).

Masyarakat yang netral beranggapan bahwa mereka tidak ambil pusing tentang adanya ekowisata baru di lingkungan mereka dan masih ragu-ragu dalam menentukan persepsi mereka terhadap ekowisata baru ini serta dengan tingkat pendidikan mereka yang didominasi tamatan SD, SMP, dan SMA serta ada beberapa yang sudah sarjana, mereka belum mengerti bagaimana menyikapi adanya ekowisata baru di lingkungan mereka. hal ini selaras dengan definisi ahli yakni Persepsi seorang individu akan muncul terhadap suatu objek yang sifatnya spontan berdasarkan dengan apa yang ada dipikaran mereka yang didasari pada keyakinan yang kuat. (Barkah, 2008).

Masyarakat yang beranggapan positif mengatakan bahwa adanya ekowisata baru ini dapat mempengaruhi secara segnifikan dalam kehidupan mereka yakni tentang pendapatan mereka, desa mereka akan lebih dikenal oleh orang luar, serta akan ada pilihan alternatif tempat wisata jika musim liburan telah tiba.

Berdasarkan hasil perhitungan Chi kuadrat pada taraf signifikan 5\% dengn $\mathrm{dk}=2$ menunjukkan nilai $\mathrm{X}^{2}$ hitung sebesar 16,232 dan nilai $X^{2}$ tabel $(0,05)$ sebesar 113,145 . Nilai $X^{2}{ }_{\text {hitung }}>$ dari nilai $X_{\text {tabel }}^{2}$ $(0,05)$, disimpulkan bahwa tidak terdapat terdapat perbedaan signifikan frekuensi persepsi masyarakat terhadap pengemabangan ekowisata bukit paoh villa dan resto dan persepsi masyarakat cenderung netral.

\section{Tingkat Pendapatan Masyarakat Desa Pangkalan Buton Terhadap Ekowisata Air Paoh}

Tingkat pendapatan masyarakat Desa Pangkalan Buton adalah dari pendapatan keseluruhan pekerjaan utama maupun pekerjaan sampingan pertahun. Responden dalam penelitian ini dikelompokkan menjadi 3 kategori. Berdasarkan hasil wawancara terhadap 94 responden diperoleh persepsi positif sebanyak $8(8,5 \%)$, netral sebanyak 56 sampel $(59,6 \%)$, dan negatif sebanyak 30 sampel $(31,9 \%)$. Tingkat pendapatan responden disajikan pada Tabel 4.

Tabel 4. Frekuensi Responden berdasarkan Tingkat Pendapatan

\begin{tabular}{ccc}
\hline Keterangan & Frekuensi & Persentase \\
\hline Positif & 8 & $8,5 \%$ \\
Netral & 56 & $59,6 \%$ \\
Negatif & 30 & $31,9 \%$ \\
\hline Total & 94 & $100 \%$
\end{tabular}

Sumber : Data Penelitian, (2019)

Berdasarkan hasil pengamatan responden sebanyak 30 responden (31,9 dalam Tabel 4 di peroleh frekuensi kelompok tingkat pendapatan rendah $\%)$. Tingkat pendapatan sedang sebanyak 56 responden $(59,6 \%)$ dan 
tingkat pendapatan tinggi sebanyak 8 responden $(8,5 \%)$.

Frequensi responden cenderung netral. Variasi tingkat pendapatan responden dikarenakan oleh sumber penghasilan yang berbeda-beda setiap responden, sumber mata pencaharian utama responden yang dominan adalah bertani/berladang dan berkebun durian, dan lain-lain. dan hanya sedikit orang asli dari desa tersebut yang bekerja sebagai karyawan di ekowisata bukit paoh villa dan resto.

\section{Tingkat Pengetahuan Masyarakat}

Desa Pangkalan Buton Terhadap

\section{Pengembangan Ekowisata Air Paoh}

Tingkat pengetahuan masyarakat merupakan salah satu cara bagaimana menilai pengetahuan masyarakat Desa Pangkalan Buton mengenai adanya Ekowisata Bukit Paoh Villa Dan Resto. Berdasarkan hasil wawancara terhadap 94 responden diperoleh persepsi positif sebanyak 9 sampel $(9,6 \%)$, netral sebanyak 65 sampel $(69,1 \%)$, dan negatif sebanyak 20 sampel $(21,3 \%)$. Tingkat pengetahuan responden disajikan pada Tabel 5.

Tabel 5. Frekuensi Responden berdasarkan Tingkat pengetahuan

\begin{tabular}{ccc}
\hline Keterangan & Frekuensi & Persentase \\
\hline Positif & 9 & $9,6 \%$ \\
Netral & 65 & $69,1 \%$ \\
Negatif & 20 & $21,3 \%$ \\
\hline Total & 94 & $100 \%$ \\
\hline
\end{tabular}

Sumber : Data Penelitian, (2019)

Tabel 5 menunjukkan bahwa dalam tingkat pengetahuan masyarakat responden di Desa Pangkalan Buton diperoleh frekuensi yang bervariasi yaitu 20 responden $(21,3 \%)$ termasuk dalam tingkat pengetahuan kategori rendah, 65 responden $(69,1 \%)$ termasuk dalam tingkat pengetahuan kategori sedang, dan 9 responden $(9,6 \%)$ termasuk dalam tingkat pengetahuan kategori tinggi. Hal ini menunjukkan bahwa 65 responden $(69,1 \quad \%)$ diperoleh kelompok pengetahuan yang terbanyak.

Masyarakat Desa Pangkalan Buton yang cenderung mempunyai pendapat netral mereka mengatakan bahwa cukup mengetahui adanya keberadaan Ekowisata Bukit Paoh Villa Dan Resto dan juga pernah datang ke Ekowisata tersebut.

\section{Tingkat Kosmopolitan Masyarakat Desa Pangkalan Buton Terhadap Ekowisata Air Paoh}

Tingkat kosmopolitan merupakan suatu teori atau konsep yang dapat dipahami sebagai pengetahuan akan manusia yang mampu menerima, menyaring dan menyerap informasi yang baik sehingga terjadi perubahan pada diri mereka berdasarkan informasi tersebut. Tingkat kosmopolitan masyarakat sekitar kawasan pengembangan ekowisata bukit paoh villa dan resto ini di kelompokkan menjadi 3 kategori. Berdasarkan hasil wawancara terhadap 94 responden diperoleh persepsi positif sebanyak 15 sampel (16\%), netral 
sebanyak 62 sampel $(65,9 \%)$, dan

Tingkat kosmopolitan

responden negatif sebanyak 17 sampel $(18,1 \%)$. disajikan pada Tabel 6 .

Tabel 6. Frekuensi responden berdasarkan tingkat kosmopolitan

\begin{tabular}{ccc}
\hline Keterangan & Frekuensi & Persentase \\
\hline Positif & 15 & $16 \%$ \\
Netral & 62 & $65,9 \%$ \\
Negatif & 17 & $18,1 \%$ \\
\hline Total & 94 & $100 \%$
\end{tabular}

Sumber : Data Penelitian, (2019)

Tabel 6 menunjukkan bahwa dalam tingkat kosmopolitan responden di Desa Pangkalan Buton diperoleh frekuensi yang bervariasi yaitu 17 responden $(18,1$ $\%$ termasuk dalam tingkat kosmopolitan kategori rendah, 62 responden $(65,9 \%)$ termasuk dalam tingkat kosmopolitan kategori sedang, dan 15 responden (16\%) termasuk dalam tingkat kosmopolitan kategori tinggi. Hal ini menunjukkan bahwa 62 responden $(65,9 \%)$ diperoleh kelompok kosmopolitan yang terbanyak.

Masyarakat Desa Pangkalan Buton yang cenderung mempunyai tingkat kosmopolitan sedang adalah masyarakat yang memiliki pengetahuan atau daya tangkap sedang terhadap pengembangan ekowisata bukit paoh villa dan resto di desa mereka yang memperoleh dan mencari informasi dari alat telekomunikasi seperti Handphone, televisi maupun radio untuk mendapatkan informasi tentang ekowisata bukit paoh villa dan resto.

\section{Analisis Inferensial}

\section{Hubungan Variabel Terikat Dan Variabel Bebas}

Menganalisis dan mengetahui hubungan variabel terikat dan variabel bebas di lakukan dengan uji Korelasi Pearson yang terdiri 1 (satu) variabel terikat yaitu persepsi dan 3 (tiga) variabel bebas yakni tingkat pengetahuan, pendapatan dan kosmopolitan. Hasil uji Korelasi Pearson variabel terikat dan variabel bebas disajikan pada Tabel 7 berikut ini.

Tabel 7. Hasil Uji Korelasi Pearson Hubungan antara Variabel Terikat dan Variabel Bebas

\begin{tabular}{cccccc}
\hline No & Variabel & N & Koefisien korelasi & Sig (2-Tailed) & Keterangan \\
\hline 1 & Pendapatan & 94 & 0,280 & 0,006 & Signifikan \\
2 & Kosmopolitan & 94 & 0,263 & 0,010 & Signifikan \\
3 & Pengetahuan & 94 & 0,233 & 0,024 & signifikan \\
\hline
\end{tabular}

Sumber : Hasil Data Penelitian, (2019)

A. Tingkat Pendapatan masyarakat terhadap Ekowisata Air Paoh

Berdasarkan hasil Uji Korelasi Pearson diketahui antara tingkat pendapatan dengan persepsi diketahui nilai sig (2-tailed) sebesar 0,006 dan correlation coefficient 0,280 . Nilai sig $0,006>0,05$, menunjukkan bahwa terdapat hubungan positif dan signifikan 
antara variabel tingkat pengetahuan dan tingkat persepsi terhadap pengembangan Ekowisata Bukit Paoh Villa Dan Resto di Desa Pangkalan Buton Kecamatan Sukadana Kabupaten Kayong Utara.

Masyarakat setempat yang memiliki usaha warung di dekat kawasan ekowisata mengatakan bahwa pendapatan mereka bertambah seiring adanya pengembangan ekowisata baru ini dikarenakan banyaknya pengunjung yang datang ke wisata baru tersebut dan pendapatan mereka relatif bertambah pada saat hari-hari besar dan hari libur seperti hari libur lebaran, tahun baru, libur sekolah, dan lain-lain.

Masyarakat mengatakan bahwa pendapatan mereka relatif bertambah karena dalam banyaknya pengunjung yang datang, masyarakat berinisiatif memberlakukan tarif parkir di sekitar lokasi wisata tersebut, selain memberikan manfaat bagi pengunjung yakni perasaan aman dari kehilangan barang tentunya juga memberikan tambahan uang bagi masyarakat khususnya masyarakat disekitar tempat wisata tersebut. Sesuai dengan tujuan ekowisata yakni Meningkatkan Daya tarik wisata, mewujudkan dan menggerakkan perekonomian daerah (Nafi, 2017).

\section{B. Tingkat Pengetahuan dengan pengembangan Ekowisata Air Paoh}

Berdasarkan hasil Uji Korelasi Pearson diketahui antara tingkat pengetahuan dengan persepsi diketahui nilai sig (2-tailed) sebesar 0,024 dan correlation coefficient 0,233 . Nilai sig
0,024>0,05, menunjukkan bahwa terdapat hubungan positif dan signifikan antara variabel tingkat pengetahuan dan tingkat persepsi terhadap pengembangan Ekowisata Air Paoh di Desa Pangkalan Buton Kecamatan Sukadana Kabupaten Kayong Utara.

Masyarakat setempat berpendapat bahwa keberadaan ekowisata bukit paoh villa dan resto adalah salah satu upaya untuk melestarikan lingkungan karena masyarakat sudah paham bagaimana melestarikan wisata mereka berdasarkan pengalaman dan pengetahuan mereka yang mereka miliki ikut menjaga kelestarian ekowisata air paoh dahulu dengan tingkat pengetahuan yang baik/tinggi umumnya memiliki kapasitas pemahaman yang baik/tinggi pula guna menjelaskan hasil pengamatan dan pengalaman di lapangan. Hal ini selaras dengan pernyataan dari yakni tingkat penegtahuan tentang sesuatu berpengaruh terhadap persepsi dan perilakunya, artinya semakin tinggi tingkat pengetahuan seseorang maka diharapkan persepsinya dan peran serta perilakunya semakin bertambah baik (yulius, 2013)

\section{Tingkat kosmopolitan masyarakat terhadap pengembangan \\ Ekowisata Air Paoh}

Berdasarkan hasil Uji Korelasi Pearson diketahui antara tingkat kosmopolitan dengan persepsi diketahui nilai sig (2-tailed) sebesar 0,010 dan correlation coefficient 0,263 . Nilai sig $0,010>0,05$, menunjukkan bahwa terdapat hubungan positif dan signifikan antara variabel tingkat kosmopolitan dan 
tingkat persepsi terhadap pengembangan Ekowisata Air Paoh di Desa Pangkalan Buton Kecamatan Sukadana Kabupaten Kayong Utara.

Kondisi masyarakat desa pangkalan buton yang didominasi oleh masyarakat yang berpendidikan rendah (tidak tamat sekolah, tamatan SD, sampai tamatan SMP) dan juga didominasi oleh pekerjaan sehari-hari sebagai petani, masyarakat belum begitu tau tentang informasi baru mengenai keberadaan ekowisata baru ini karena prioritas atau pilihan utama mereka adalah bekerja dan ketika pada malam harinya mereka beristirahat.

\section{KESIMPULAN}

1. Persepsi masyarakat sekitar kawasan pengembangan ekowisata Air Paoh di Desa Pangkalan Buton Kecamatan Sukadana Kabupaten Kayong Utara cenderung netral

2. Terdapat hubungan yang signifikan dan positif antara tingkat pendapatan dengan persepsi masyarakat terhadap sekitar kawasan pengembangan Ekowisata Air Paoh, terdapat hubungan yang signifikan dan positif antara tingkat pengetahuan dengan persepsi masyarakat terhadap sekitar kawasan pengembangan Ekowisata Air Paoh , terdapat hubungan yang signifikan dan positif antara kosmopolitan dengan persepsi masyarakat terhadap sekitar kawasan pengembangan Ekowisata Air Paoh.

\section{SARAN}

Adanya persepsi netral dari masyarakat Desa Pangkalan Buton terhadap pengembangan Ekowisata Air
Paoh, maka diharapkan kepada pihak swasta untuk bekerja sama dengan pemerintah daerah untuk meningkatkan kesadaran masyarakat setempat dengan memberikan penyuluhan atau sosialisasi supaya masyarakat lebih dapat mengetahui Ekowisata Bukit Paoh Villa dan Resto tersebut.

\section{Ucapan Terima Kasih}

Penulis mengucapakan terima kasih kepada masyarakat Desa Pangkalan Buton Kecamatan Sukadana Kabupaten Kayong Utara yang telah mengizinkan melakukan penelitian di desa tersebut dan telah memberikan respon yang sangat baik serta bersedia memberikan informasi dan ilmu yang berkaitan dengan penelitian sehingga penelitian ini berjalan dengan lancar tanpa suatu kendala apapun.

\section{DAFTAR PUSTAKA}

Asmin F. 2014. Ekowisata Dan Pembangunan Berkelanjutan: Dimulai Dari Konsep Sederhana. Bogor: Bogor Agricultural University.

Barkah. 2008. Pengaruh Persepsi dan Lingkungan Individu Pengunjung Terhadap Kepuasan Belanja di Mall di Kota Pontianak. Jurnal Penelitian Universitas Tanjungpura Pontianak 11 (3).

Boediono. 2002. Ekonomi Makro: Seri Sinopsis Pengantar Ilmu Ekonomi No.1 Edisi 2. Yogyakarta: BPFE Yogyakarta.

Departemen Kehutanan. 1987. Wisata Dalam Beberapa Aspek. Dinas Kehutanan Provinsi Kalimantan Barat. Pontianak. 
Fandeli C, Mukhlison. 2000. Pengusahaan ekowisata. Fakultas Kehutanan Universitas Gadjah Mada. Yogyakarta: Pustaka Pelajar.

Idrus M. 2009. Metode Penelitian Ilmu Sosial. Pendekatan Kualitatif dan Kuantitatif. Jakarta: Erlangga.

Nafi M, Supriadi B, Roedjinandari N. 2017. Pengembangan Ekowisata Daerah. Buku Bunga Rampai tahun 2017. Malang: Universitas Merdeka

Ni'am AL, Mussadun. 2014. Dampak Aktivitas Ekowisata di Pulau Karimunjawa Berdasarkan Persepsi Masyarakat. Jurnal Teknik PWK 3 (2): 262-273.

Novayanti D, Banuwa IS, Safe'i R, Wulandari C. 2017. Analisis Faktor-Faktor yang
Mempengaruhi

Persepsi Masyarakat dalam Pembangunan Hutan Tanaman Rakyat pada KPH Gedong Wani. Jurnal Hutan dan Masyarakat 9 (2): 61-74.

Satria YY, Surachman M. Purwanti. 2013. Persepsi Masyarakat Terhadap Usaha Tani Tanaman Karet (Havea Brasiliensis) di Desa Nanga Tekungai Kecamatan Serawai Kabupaten Sintang. Jurnal Hutan Lestari 1 (3): 301307.

Silaen S, Widiyono. 2013. Metodologi Penelitian Sosial Untuk Penulisan Skripsi Dan Tesis. Bogor: In Media.

Sugiyono. 2011. Metode Penelitian Pendidikan (pendekatan kuantitatif, kualitatif, dan $R \& D)$. Bandung: Alfabeta. 